\title{
Effects of Heat Input and Niobium Addition on HAZ of Microalloyed Steels for Reinforcing Bars
}

\author{
Juscelino Mendes Prado ${ }^{1}$ (D), Roney Eduardo Lino ${ }^{1}$, Cláudio Turani Vaz ${ }^{1}$ \\ ${ }^{1}$ Centro Federal de Educação Tecnológica de Minas Gerais - CEFET-MG, Departamento de Engenharia de Materiais, Belo Horizonte, MG, Brasil.
}

How to cite: Prado JM, Lino RE, Vaz CT. Effects of heat input and niobium addition on HAZ of microalloyed steels for reinforcing bars. Soldagem \& Inspeção. 2020;25:e2531. https://doi.org/10.1590/0104-9224/SI25.31

\begin{abstract}
Niobium or vanadium addition provides homogeneous microstructures formation, strengthening and toughness improvement in steels. However, alloying elements increase can negatively affect Pcm (material parameter) value, which can lead to deleterious effects under welding conditions. Thus, welding trials were carried out on a novel microalloyed steel with $0.2 \% \mathrm{C}$ by autogenous GTAW (Gas-Shielded Tungsten Arc Welding) process. The results indicate that coarse grains region of heat affected zone (CGHAZ) is the most critical area. This was due abnormal grains size $(>100 \mu \mathrm{m})$, achieving more than 4 times the average size of base metal (BM) grains, or the presence of high hardness microstructures. In addition, the results do not indicate softness in any region of HAZ, proving to be an advantage of these materials.
\end{abstract}

Key-words: Welding; Microalloyed steels; HAZ; Heat input.

\section{Influência do Aporte Térmico e da Adição de Nióbio na ZTA de Aços Microligados para Aplicação Estrutural}

\begin{abstract}
Resumo: A adição de nióbio ou vanádio favorece a formação de microestruturas homogêneas, aumenta a resistência mecânica e a tenacidade dos aços. No entanto, a adição desses elementos de liga pode afetar negativamente o valor do $\mathrm{Pcm}$ (material parameter) o que pode levar a efeitos deletérios sob certas condições de soldagem. Dessa maneira, foram realizados testes em barras de um novo tipo de aço microligado com $0,2 \% \mathrm{C}$, pelo processo GTAW (Gas-shielded Tungsten Arc Welding). Os resultados indicam a região de grãos grosseiros da ZTA como sendo o local de maior criticidade durante a soldagem. Isso devido à presença de grãos com crescimento anormal (>100 $\mu \mathrm{m}$ ), alcançando uma média superior a 4 vezes a do metal base, ou a presença de microestruturas de alta dureza. Em contrapartida, os resultados não indicam a redução de dureza em nenhuma região da ZTA, mostrando uma vantagem desses materiais.
\end{abstract}

Palavras-chave: Soldagem; Aços microligados; ZTA; Aporte térmico.

\section{Introduction}

Millions of tons of high strength reinforcing steels are used every year in heavy civil construction. These steels, that are known as reinforcing bars or simply rebars, represent at least one-fourth of total steel produced in the world [1]. These rebars provide essential strength and stability to the concrete, including the capacity of minimize damages during earthquakes [2,3]. Thus, the improvement of this type of material, in terms of mechanical properties, has been studied in the recent years. It is well known that the most common steel used for that purpose is produced by Tempcore ${ }^{\circledR}$ process. However, rebars produced by this type of process has some restriction in welding because of heterogeneous microstructure formed by perlite, bainite and an external ring of tempered martensite [4]. Nonetheless, as an alternative, a novel microalloyed steel with addition of strong carbides formers such as V, Nb or Ti, and produced by ThermoMechanical Control Process (TMCP), have been developed [5,6]. Chemical composition, allied to appropriate processing, ensure excellent tensile strength, good toughness and can keep weldability [7].

It is common to check only chemical composition to determine weldability of steels. Hence, equivalent carbon value (CE) or material parameter $(\mathrm{Pcm})$ are always calculated to stablish it. However, other parameters like heat input can also be as important as alloying elements content [8]. The Pcm, calculated by Equation 1, allows analyzes in a wider range of microalloyed steels when compared to CE formula suggested by IIW (International Institute of Welding) [9].

$P c m=C+\frac{S i}{30}+\frac{M n+C u+C r}{20}+\frac{N i}{60}+\frac{M o}{15}+\frac{V}{10}+5 B$ 
High value of Pcm could lead to quenching tendency and cause brittle phases formation [10]. Then, Pcm value should not exceed 0.4 , due to common presence of martensite for values higher than this, which can reduce toughness and increase the possibility of cold embrittlement or hydrogen embrittlement [11]. As well as heat input also plays an important role in microstructure control. This can influence microstructure in heat affected zone (HAZ) through some aspects. Firstly, a high welding heat input promote a low cooling rate and gives time and energy to the system, favoring the growth of prior austenite grains and, then, the enlargement of grains on CGHAZ, which can deteriorate the main strengthening mechanism in this type of steel. In another hand, the welding heat input reduction may increase cooling rate and then promote brittle constituent formation in HAZ [10], which can cause toughness decrease. Finally, the control of heat input is also important due to the link with the HAZ width in welding processes.

Therefore, due to the increasing demand for high strength steels used in structural application, in 2014 was launched a research about the development of a microalloyed steel, with $\mathrm{V}, \mathrm{Nb}$ and $0.2 \% \mathrm{C}$, for applications as reinforcing bars. As a result, a study was pointed out the effect of $\mathrm{Nb}$ addition and heat input in welded joints [5], especially regarding microstructure and mechanical properties of heat affected zone (HAZ).

In this research, the welding effects at HAZ when chemical composition and heat input are variated, was discussed. Thus, this paper provides guidance for welds designs of high equivalent carbon steels microalloyed with $\mathrm{V}$ and $\mathrm{Nb}$.

\section{Experimental Procedures}

Experiments were done on $20 \mathrm{~mm}$ diameter reinforcing bars cut to a length of $220 \mathrm{~mm}$ made with microalloyed steels with different $\mathrm{Nb}$ contents. Chemical composition, $\mathrm{Pcm}$ value and hardness $\left(\mathrm{HV}_{0.2}\right)$ of base metal, which can be correlated with tensile strength [12], are summarized in Table 1. Note that, only Nb content was variate significantly, thus two types of steel were tested: $\mathrm{Nb}$ free steel $(\mathrm{V})$ and another steel with $\mathrm{Nb}$ addition (NbV).

Table 1. Chemical composition of the studied steels in mass percentage.

\begin{tabular}{ccccccccccccc}
\hline Steel & $\mathbf{C}$ & $\mathbf{M n}$ & $\mathbf{P}$ & $\mathbf{C r}$ & $\mathbf{S i}$ & $\mathbf{N i}$ & $\mathbf{N b}$ & $\mathbf{V}$ & $\mathbf{C u}$ & $\mathbf{M o}$ & $\mathbf{P c m}$ & $\mathbf{H V}$ \\
$\mathrm{NbV}$ & 0.26 & 1.2 & 0.0015 & 0.13 & 0.39 & 0.011 & $\mathbf{0 . 0 1 5}$ & 0.10 & 0.014 & 0.001 & 0.36 & 273 \\
$\mathrm{~V}$ & 0.25 & 1.2 & 0.0017 & 0.12 & 0.38 & 0.013 & $\mathbf{0 . 0 0 1}$ & 0.11 & 0.017 & 0.002 & 0.34 & 259 \\
\hline
\end{tabular}

The proposition was to study only HAZ and GTAW autogenous welding process was chosen because it allows an excellent heat input control without filler metal, i.e, it is the most suitable option for this work. A $2.4 \mathrm{~mm}$ AWS EWTh-1 electrode, 3.2mm arc length and Argon as shielding gas with a flow rate of $10 \mathrm{~L} / \mathrm{min}$ were used. Welding speed, voltage, current and heat input are presented in Table 2.

Table 2. Characteristics of welding.

\begin{tabular}{ccccc}
\hline & Welding speed $(\mathrm{mm} / \mathrm{min})$ & Voltage $(\mathrm{V})$ & Current $(\mathrm{A})$ & Heat Input $(\mathrm{kJ} / \mathrm{mm})$ \\
Low HI & 120 & 15 & 200 & 1.0 \\
High HI & 288 & 15 & 200 & 0.4 \\
\hline
\end{tabular}

Note that the welding heat input $(\mathrm{HI})$ was calculated by Equation 2. Where I, $\mathrm{V}, \mathrm{v}$, and $\eta$ are the current, voltage, speed, and arc efficiency in applied welding process, respectively. The arc efficiency was set at 0.7 [13].

$$
H I=\eta \frac{V I}{v}
$$

Automatic autogenous GTAW process was carried out as shown in Figure 1. As can be seen, three type J thermocouples were positioned at $3 \mathrm{~mm}$ depth from bar surface to monitor thermal cycle and check variation at different bar positions during welding, which can justify microstructural and mechanical changes.

Figure $2 \mathrm{~A}$ shows an example of a bar welded in the surface by GTAW process, simulating a welding process. Figure 2B represents the sampling method, note that three samples were taking from each welded bar in the same position occupied for thermocouples $1 / 4$ (position 1 ), $1 / 2$ (position 2), and $3 / 4$ (position 3) of weld bead length. After that, metallographic analysis and hardness profile were carried out. In Figure $2 \mathrm{C}$ can be seen a macrography of a welded sample with the main analyzed regions and the borders taken as reference.

As shown in Table 3, an experimental design was carried out with two independent variables or factors, named: heat input and chemical composition. Two levels were chosen for each factor. Specifically: $0.4 \mathrm{~kJ} / \mathrm{mm}$ and $1.0 \mathrm{~kJ} / \mathrm{mm}$ for heat input and steel with $\mathrm{Nb}$ addition and $\mathrm{Nb}$ free steel. 


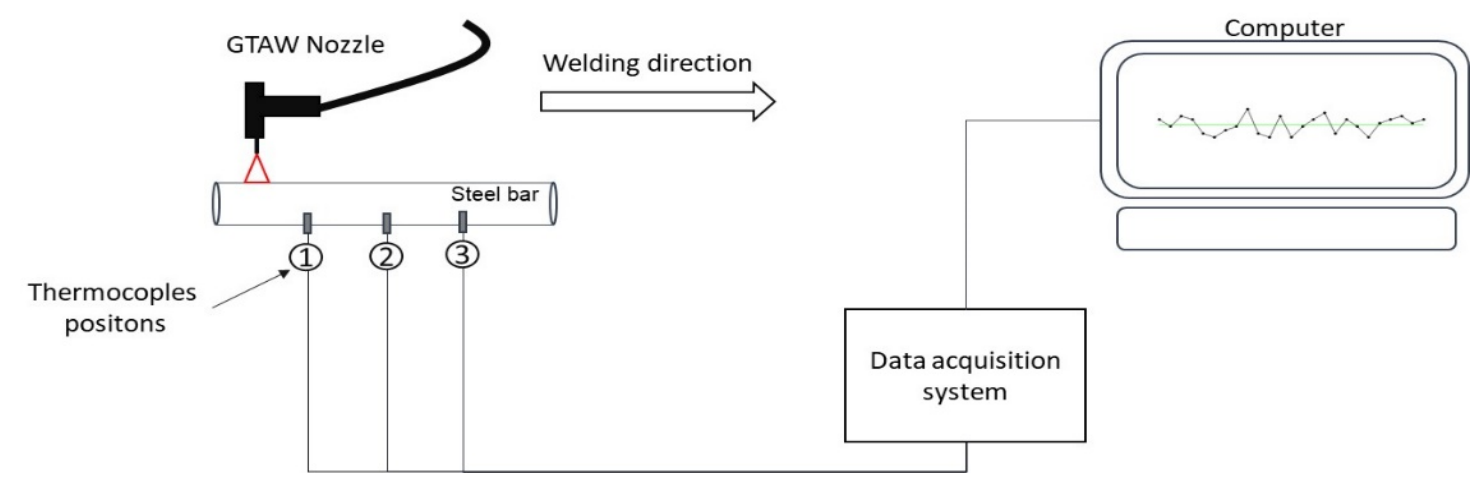

Figure 1. Schematic for GTAW process of steel bar without filler metal and data acquisition system linked to computer. The welding was performed by a travel mechanism automatically.
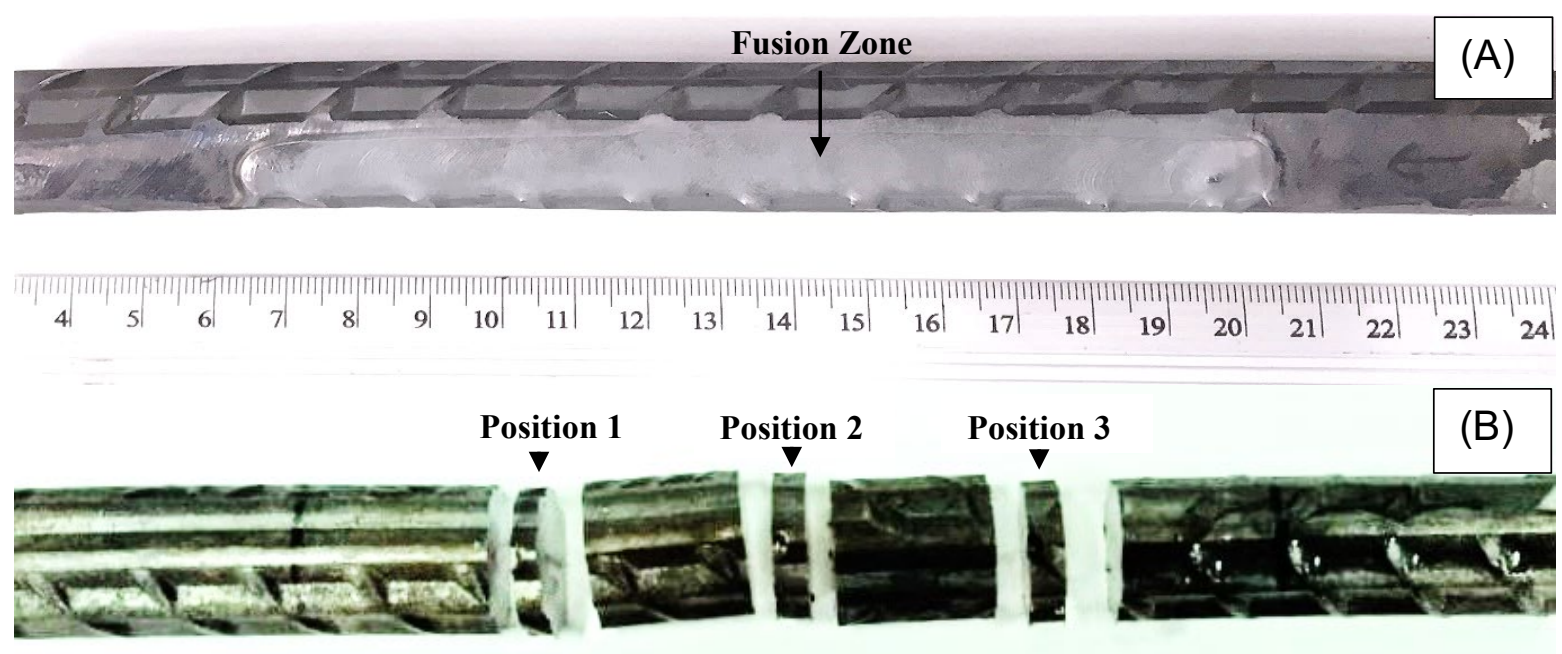

(C)

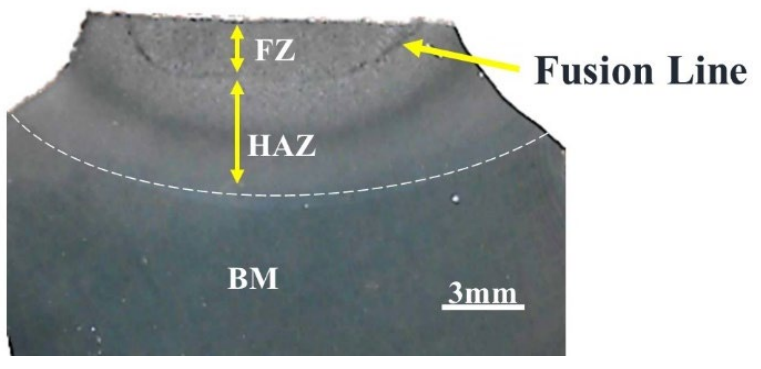

Figure 2. Welded bars (A) Bar after welding (B) Places where samples were taken in a welded bar (C) Macrography of a welded sample

Table 3. Tested factors with respective levels.

\begin{tabular}{ccc}
\hline & & Levels \\
Factors & -1 & +1 \\
Heat input & $0.4 \mathrm{~kJ} / \mathrm{mm}$ & $1.0 \mathrm{~kJ} / \mathrm{mm}$ \\
Chemical composition & $\mathrm{Nb}$ free & With Nb addition \\
\hline
\end{tabular}

Microstructure observations were conducted by optical microscopy (OM) and scanning electron microscopy (SEM). Specimens were cut from the center of thermocouple welding point, polished and etched with $2 \%$ nital solution for OM and SEM observations. The Vickers microhardness of the polished samples was measured using hardness tester with $0.2 \mathrm{Kg}$ load and $15 \mathrm{~s}$ of indentation time. The distance between every two adjacent test points was minimum of three times indentation mark length [14]. 
An adaptation of intercept method provided by ASTM standard [15] was necessary for grains size measurements. This consist in parallel lines drawn from fusion line using ImageJ software. The fusion line was the one that separates the columnar grains from the molten zone of the equiaxial grains in CGHAZ and the transition between CGHAZ and FGHAZ (Fine Grain of Heat Affected Zone) is the line from which the grains are about BM grain size.

According to the number of levels and factors chosen, 4 trials was reached, as indicated in the experiment matrix (Table 4). This was due to the choice of the complete factorial design $2^{k}[16]$, where 2 is the number of levels and $k$ is the number of factors. Thus, according to the planning, trials were carried out varying the chemical composition and heat input, where Nb free steels $\mathrm{Nb}(-1)$, steels with $\mathrm{Nb}$ addition $(+1)$, welding at low heat input $(-1)$ were welded and welding at high heat input $(+1)$. In addition, the number of replicates was 3, this means that, for each welding condition, 3 bars were tested. Thus, trials were carried out on $6 \mathrm{NbV}$ steel bars and $6 \mathrm{~V}$ steel bars, totaling 12 welded bars. Finally, 3 samples were taken from each welded specimen, reaching a total of 36 samples for characterization via optical microscopy, SEM and Vickers microhardness tests.

Table 4. Factorial experiment design matrix.

\begin{tabular}{cccc}
\hline Trial & Nb addition & Heat Input \\
1 & -1 & -1 \\
2 & +1 & -1 \\
3 & -1 & +1 \\
4 & +1 & +1 \\
\hline
\end{tabular}

\section{Results and Discussion}

Steels microstructures, as received, were analyzed and no major differences were observed by OM, both are formed by ferrite and perlite (Figure 3A). To confirm perlite constituents (in dark), scanning electron microscopy (SEM) analyses were performed, and as predicted, the results were confirmed as presented in Figure 3B.

(A)

\section{Optical Microscopy}
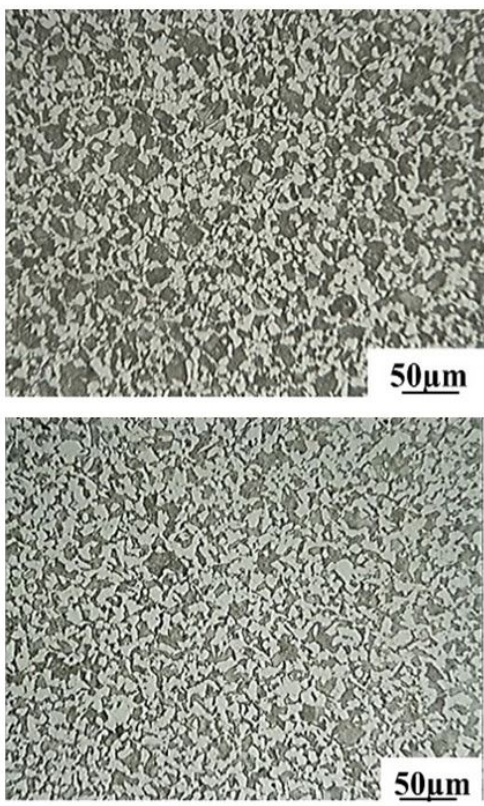

(B)

\section{Scanning Electron Microscopy}
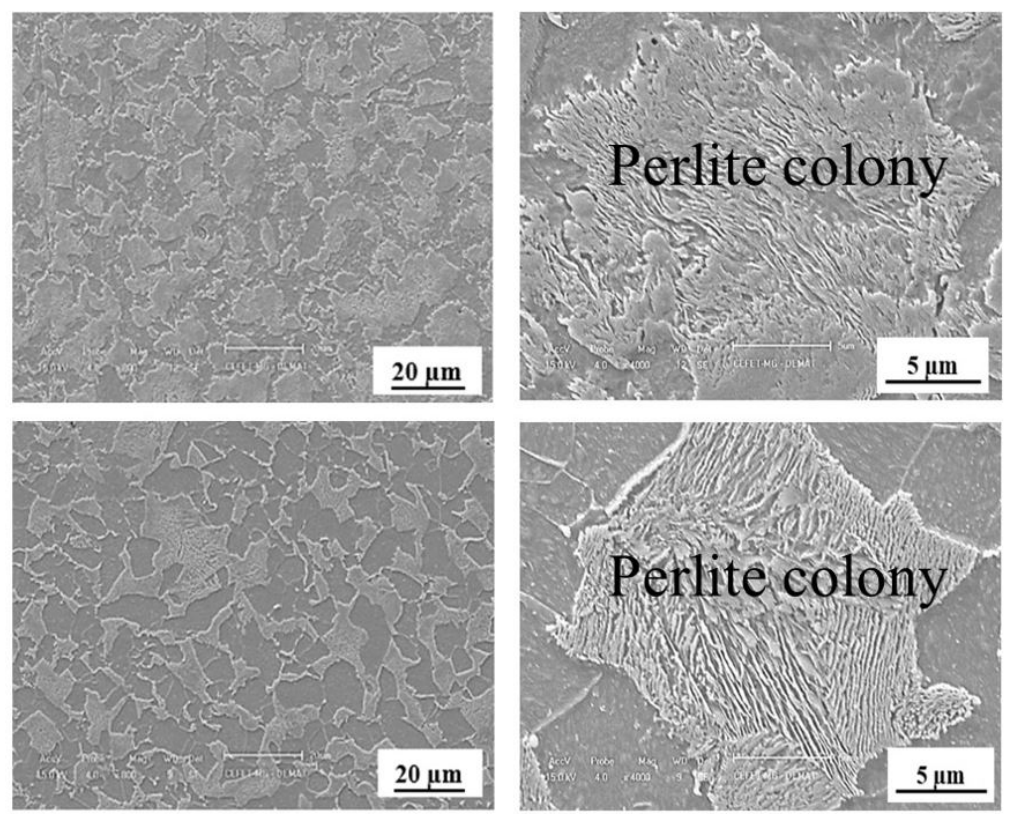

Figure 3. Results for SEM and OM analysis in samples of BM.

The welding thermal cycles were obtained by data acquisition system. Figure $4 \mathrm{~A}$ shows for $\mathrm{V}$ steel bars welded at low and high heat input, while in Figure 4B shows thermal cycles for NbV steels welded also at low and high heat input. Can be noted which the thermal cycles are similar in the three positions of the bars ( $P 1, P 2$, and P3) for the same heat input. Therefore, any variations in HAZ microstructure or mechanical properties cannot be associated to this variable. 

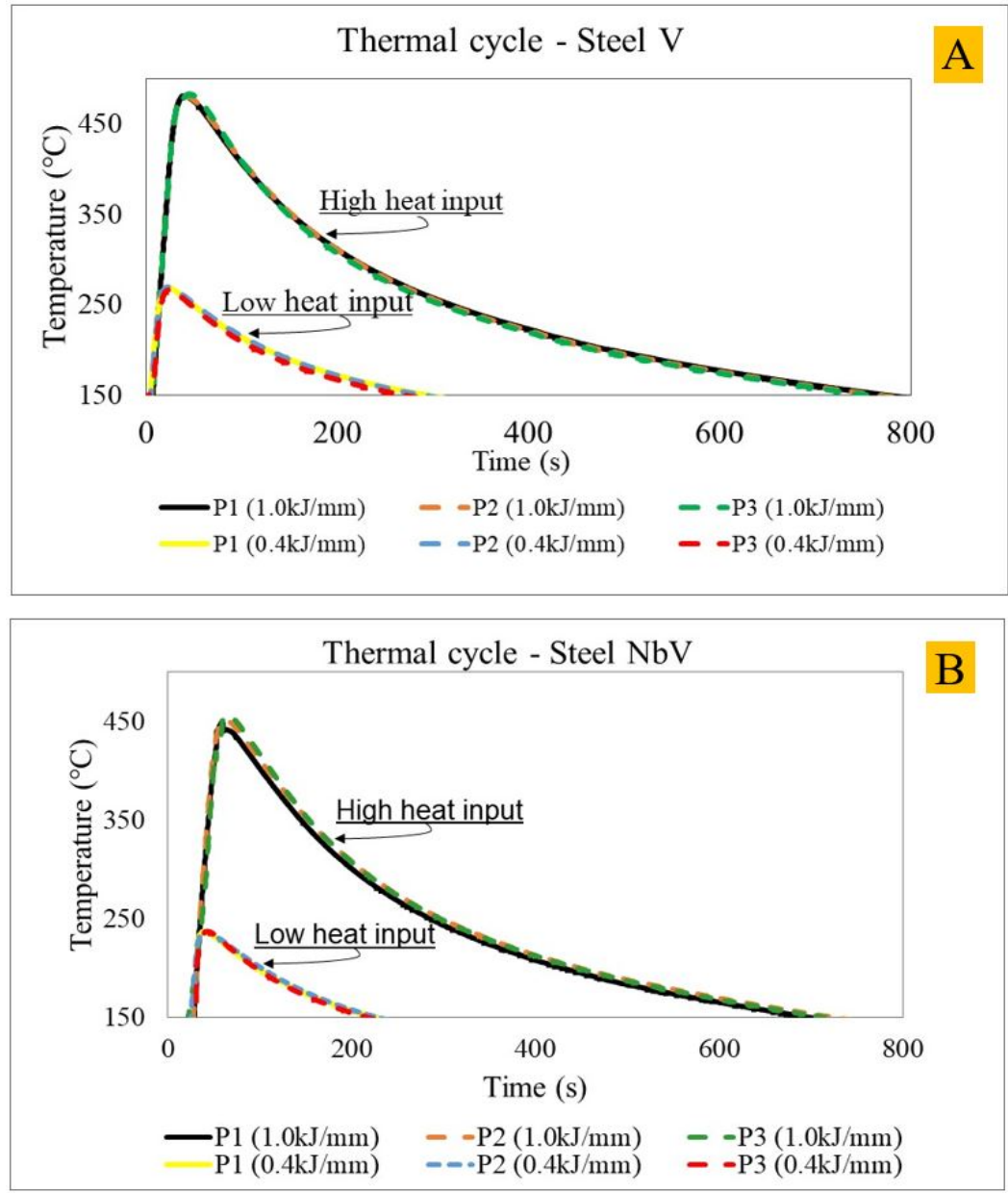

Figure 4. Thermal cycle for welded steels (A) NbV steel (B) V steel.

Measurements of HAZ width were performed on microhardness tester that has an optical microscope and two digital micrometers, the results are shown in Figure 5. As can be seen, there was an increase in this region for welded steels with high heat input $(1.0 \mathrm{~kJ} / \mathrm{mm})$. This is in accordance with that described by some researches [13,17], who affirm that the increase of $\mathrm{HAZ}$ width is proportional to the increase of heat input. Furthermore, no effect of $\mathrm{Nb}$ addition was noted in HAZ width.

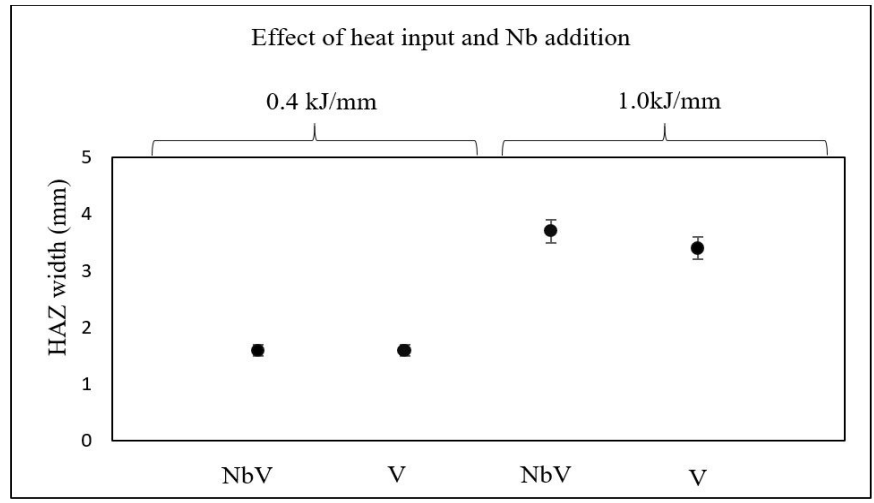

Figure 5. Data distribution for HAZ width.

The CGHAZ is considered a critical region due to its greater enlargement and visible increase in the grain size compared to BM. Thus, it was necessary an evaluation of previous austenitic grain size in this region, to verify the effects of the studied variables. Analyzing, firstly, BM and CGHAZ (Table 5) there is an evident increase of the average grain size, specially for steels welded at high heat input. Notice that for $\mathrm{Nb}$ free steel the grain size is 4 times greater when compared to initial value in BM. The deterioration of pinning effect due to achieved high temperature is noticeable. 
A second analyses, which can be seen by the results for welding at low heat input (Figure 6), shows that NbV steel presented a smaller grain size than $\mathrm{V}$ steel. This can be explained by the $\mathrm{Nb}$ addition, due the less solubilization of this element in comparison with vanadium, as described by previous papers [18], supported by the formation of carbonitrides, which were preponderant for pinning effect, consequently reducing grain size. The same analysis can be done for the results also shown in Figure 6 , however, now for welded steels with high heat input. As can be seen, there is an increase in grain size for $V$ steels and this confirms the results and hypothesis shown above. Note that, welded $\mathrm{V}$ and $\mathrm{NbV}$ steels with high heat input $(1.0 \mathrm{~kJ} / \mathrm{mm})$ presented a significant amount of abnormal grain size. In this work, abnormal grains were those that reached a diameter about $100 \mu \mathrm{m}$, since it is a grain growth that occurs in welds of high heat input, such as the submerged arc welding process for instance [19].

Table 5. Average grain size in CGHAZ and BM.

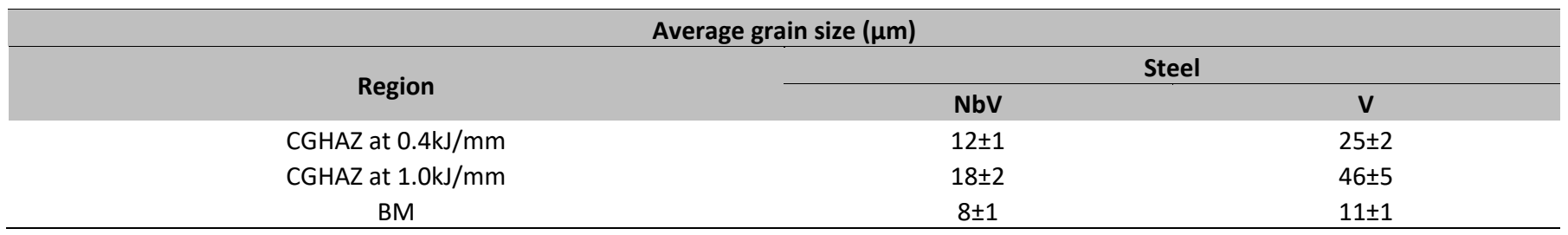

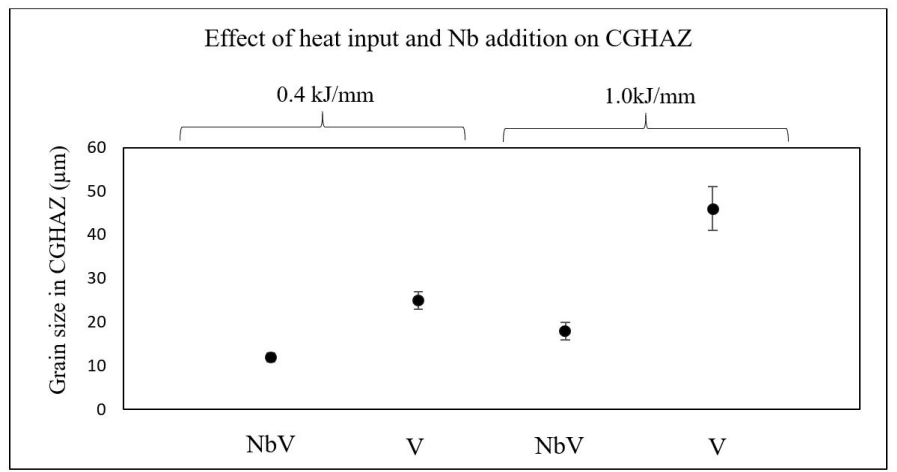

Figure 6. Data distribution for CGHAZ grain size.

As CGHAZ is the most critical region, focused analysis was done to better understanding of hardness profile and microstructural effects. For steels welded at high heat input, no difference between specimens in the three distinct analyzed regions of CGHAZ were observed. As can be seen in Figure 7, microstructures are mainly composed of allotriomorphic ferrite, perlite and some Widmanstätten ferrite can be noted.
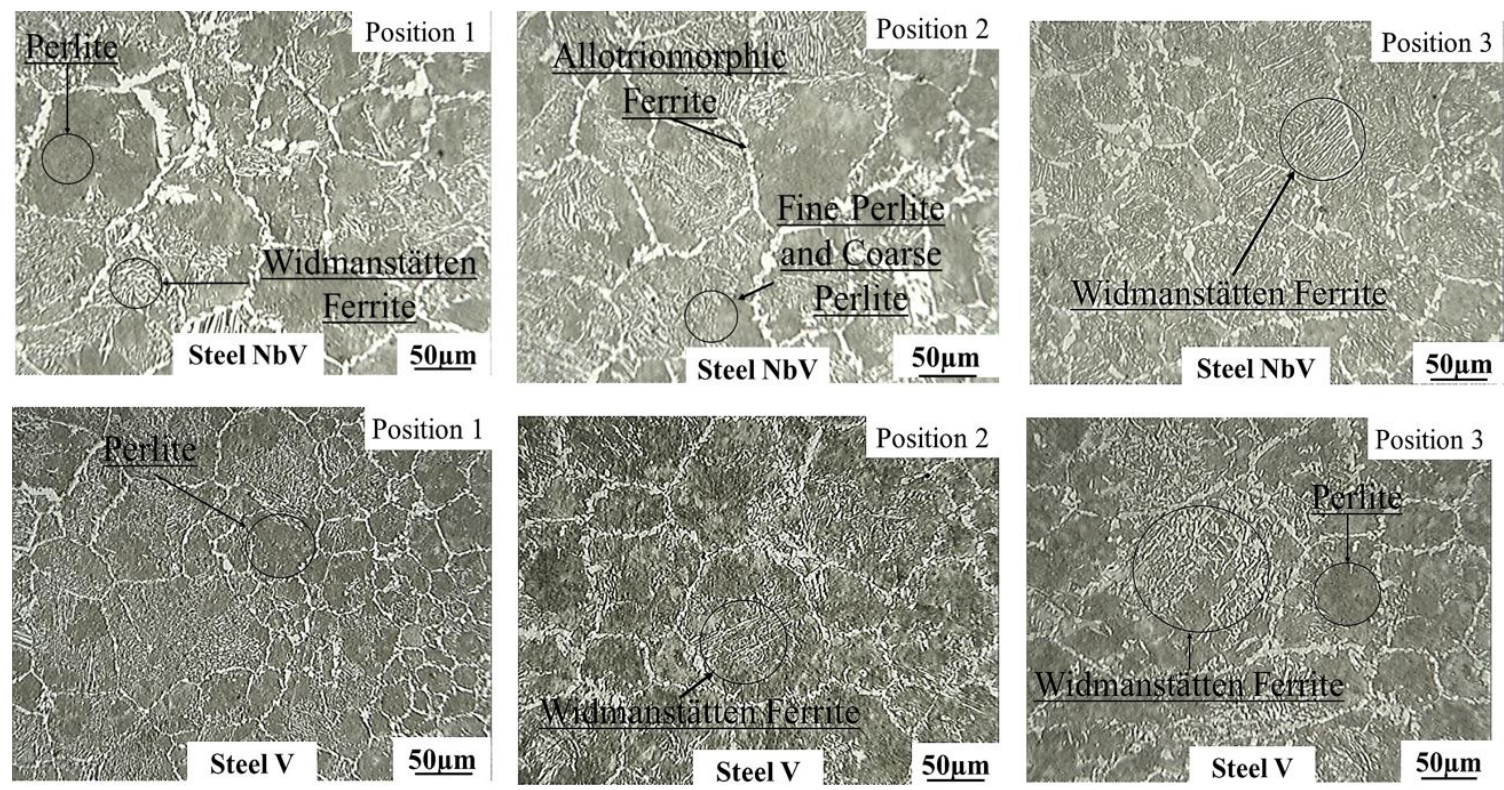

Figure 7. Micrography of CGHAZ at three different positions for high heat input welding. 
Analyzes were performed, in a sample welded at high heat input, using scanning electron microscopy for constituent's identification in the intragranular region. In addition, an analysis was made using dispersive energy spectroscopy (EDS). As showed in Figure 8 , the result of the spectrum showed the highlights of $C$ and Fe peaks, indicating the possibility of cementite lamella $\left(\mathrm{Fe}_{3} \mathrm{C}\right)$ in the analyzed perlite colony. Thus, it can be inferred that, in some regions, there was the formation of a single constituent, but with different morphologies: fine perlite and coarse perlite.
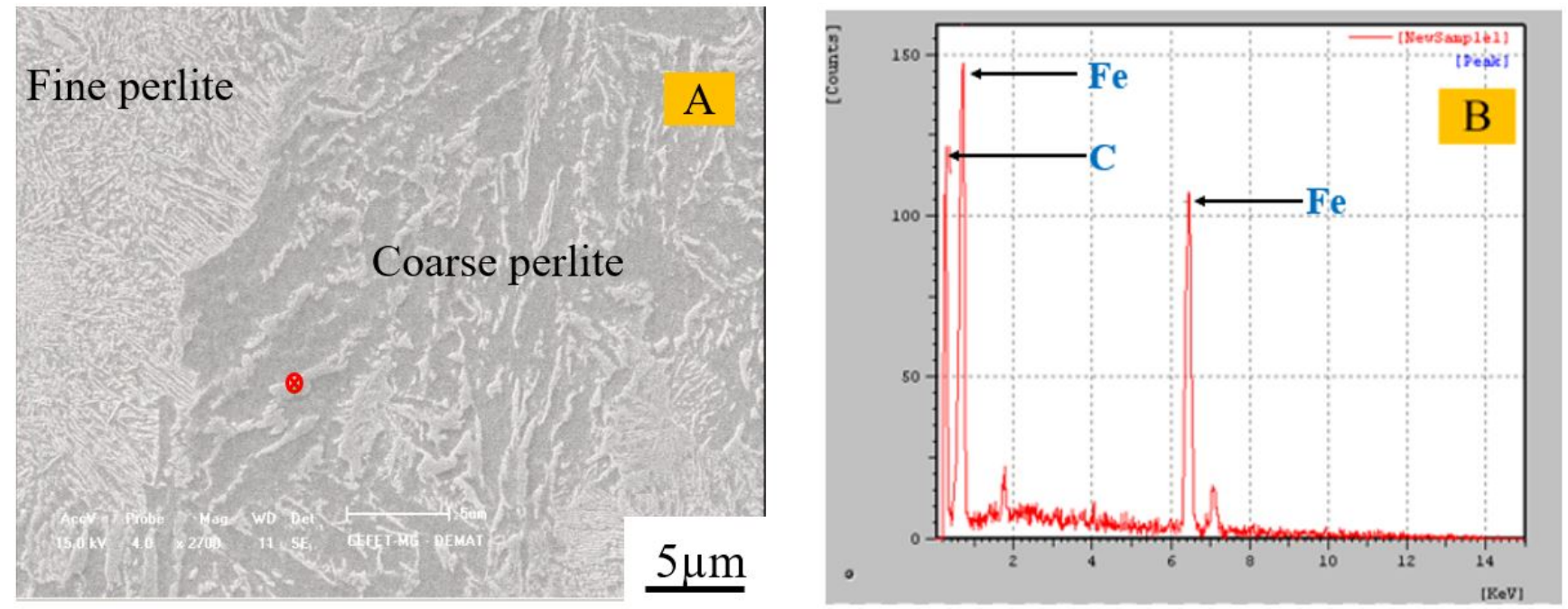

Figure 8. Constituents analyses (A) Micrography of a coarse and fine perlite colony (B) EDS results for a perlite lamella (red point).

Like the analysis for the bars where high heat input was applied, the micrographs for low heat input $(0.4 \mathrm{~kJ} / \mathrm{mm}) \mathrm{showed}$ results that confirm the thermal cycles. Samples showed similar microstructures (Figure 9) in the three positions analyzed. However, for the welded samples with low heat input, the results of the optical microscopy analysis allowed only the visualization of previous austenitic grain boundaries. This was due to an exceptionally fine microstructure in the intragranular region. Thus, further investigations with higher magnifications were necessary.
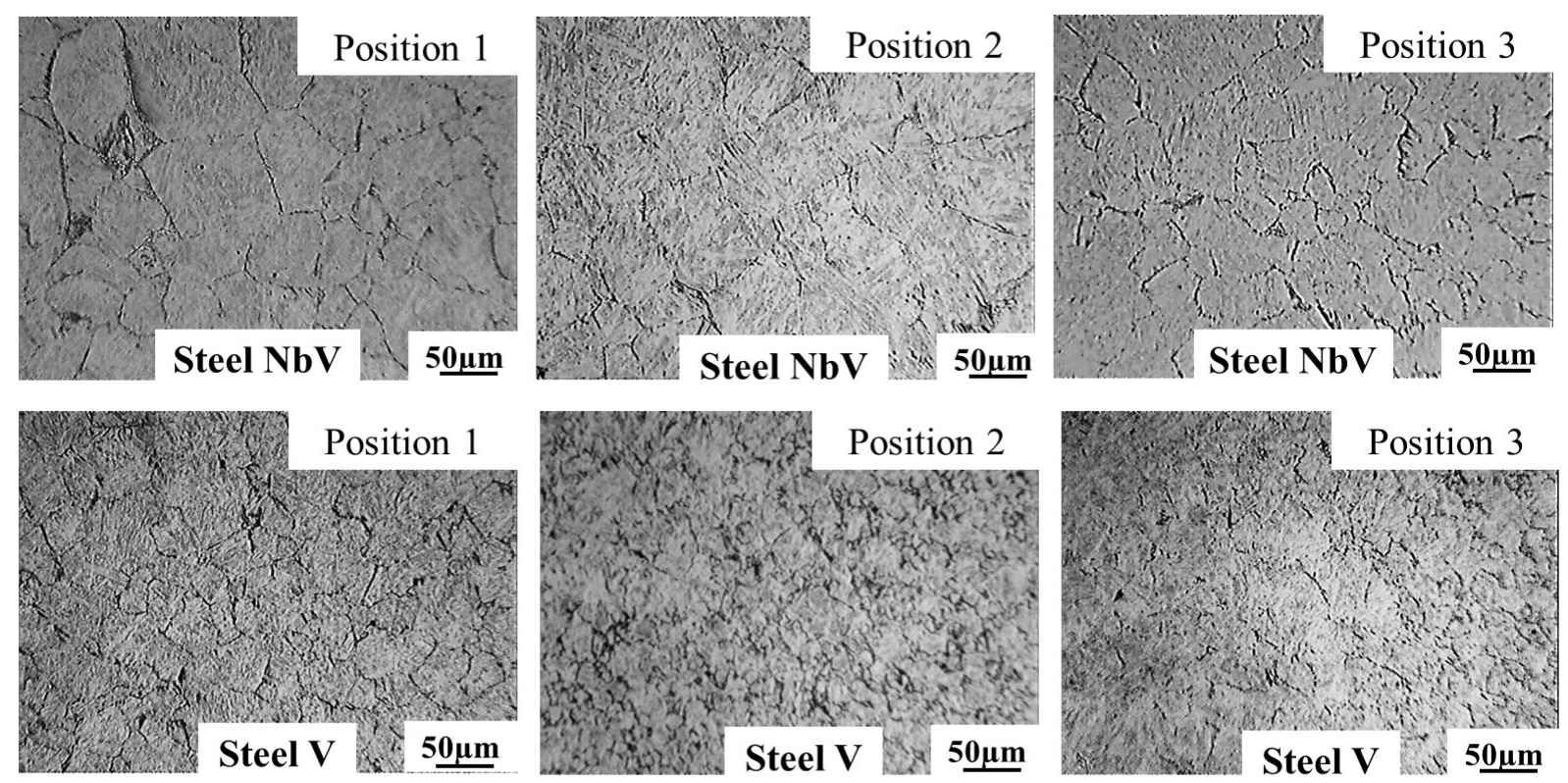

Figure 9. Optical micrography of CGHAZ at three different positions for low heat input welding.

For a better visualization of constituents in CGHAZ intragranular regions of welded steels with low heat input, analyzes were performed using SEM technique. Figure 10 shows an acicular formation growing from grain boundary, which indicates Widmanstätten ferrite. Widmanstätten ferrite formation is usually combined with fragile structures such as bainite and martensite [20]. This can be confirmed by high hardness at CGHAZ regions of welded steels with low heat input, i.e., values close 
to $500 \mathrm{HV}_{0.2}$. Yet about microstructure in intragranular region, acicular structures formation was observed, and probably it is bainite and martensite constituents which explains the high hardness values $\left(447 \mathrm{HV}_{0.2}\right)$ found in this region.

Still according to micrographs (Figure 10), steel alloyed with $\mathrm{Nb}$ presented the same characteristics of the $\mathrm{Nb}$ free steel, i.e., Widmanstätten ferrite and others acicular structures which are probably bainite and martensite. This inference is consistent with the hardness results found $\left(484 \mathrm{HV}_{0.2}\right)$. As the average hardness for NbV steel is higher than the value found for the same region for $\mathrm{Nb}$ free steel, it can be associated with a greater volume of high hardness constituents in those steels confirming the increase of hardenability caused by $\mathrm{Nb}$ addition as mentioned in a recent paper [6]. The authors shows that the move of TTT curve (Time - Temperature - Transformation) facilitate the increase volumetric fraction of high hardness structures (bainite, martensite, etc.), and also explained by other researchers [17], who showed the correlation between the reduction of heat input and the increase of high hardness structures.

Vickers microhardness $\left(\mathrm{HV}_{0.2}\right)$ trials were performed on samples with low and high heat input for both types of steels. Figure $11 \mathrm{~A}$ shows the profiles obtained for the welding conditions studied. Can be observed a tendency of hardness growth towards FZ, that is: peak temperature enhances results in higher hardness values. It is also observed that the steel with niobium presented, throughout the profile, higher hardness than $\mathrm{Nb}$ free steel.

The significant increase in CGHAZ hardness observed for both steels, for the lowest heat input, indicates microstructural changes. It can be explained by the high cooling rate generally associated to low heat input welding [17] which led to microstructures with high hardness constituents such as martensite, bainite and Widmanstätten ferrite.

In another hand, high heat input welding suggests a beneficial effect in terms of hardness. As showed in Figure 11B, microhardness profiles for $\mathrm{V}$ and NbV steels indicate lower hardness and data variability and without variation tendency. Microstructure is determinant for mechanical properties of steels [21] and lower constituents variation for welded steels at high heat input was observed, basically the microstructure found was perlite and some variation of ferrite, i.e, no high hardness microstructure was noticed in any region of HAZ. It is an advantage when the intention is to weld these materials.

Summarizing these results through the comparison of microalloying addition which, under high heat input, can promotes a large CGHAZ with low strength and Pcm which, under low heat input, generates a CGHAZ with brittle constituents, the second one should be considered mandatory.
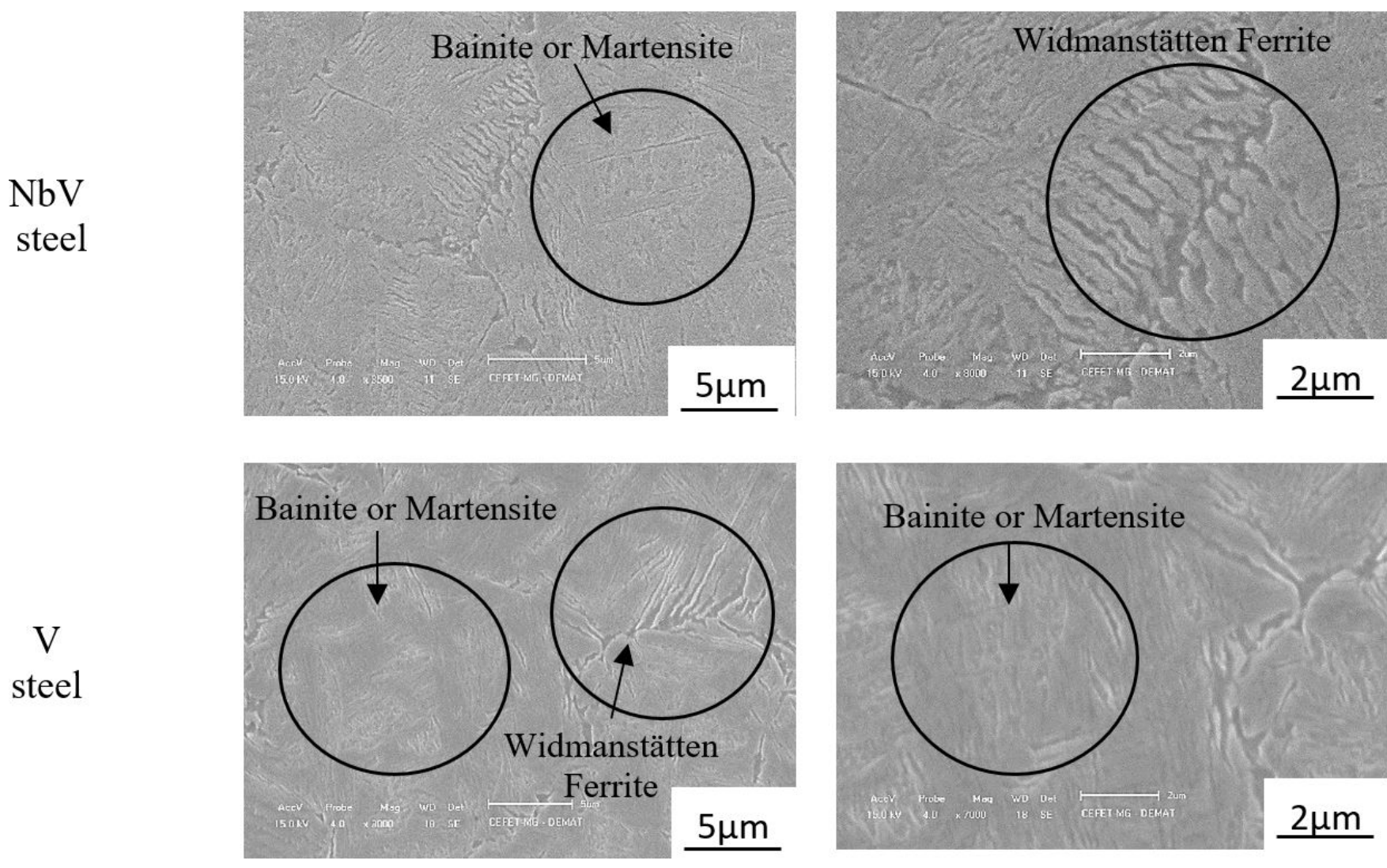

Figure 10. Results for SEM analysis in samples welded at low heat input. 

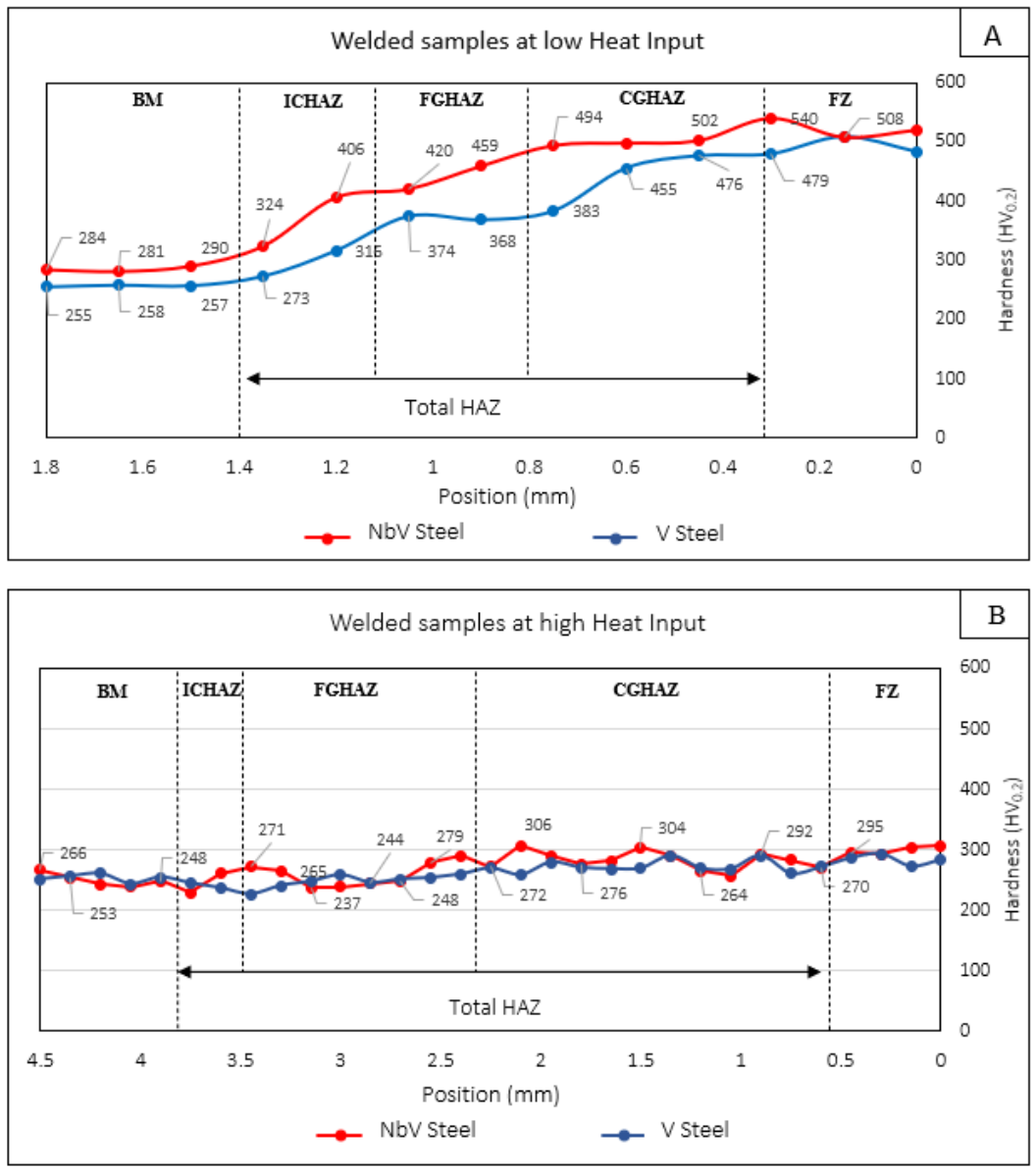

Figure 11. Hardness profiles (A) Welding at low heat input (B) Welding at high heat input.

\section{Conclusions}

To complement the development of a novel steel for reinforcing bars, the effect of $\mathrm{HI}$ and $\mathrm{Nb}$ addition on $0.2 \% \mathrm{C}$ steel on HAZ were investigated and the following conclusions were obtained:

- High heat input $(1.0 \mathrm{~kJ} / \mathrm{mm})$ caused abnormal grain growth on CGHAZ $(>100 \mu \mathrm{m})$. In addition, high heat input led to increased HAZ width. Thus, heat input needs to be used with caution, once it can increase HAZ, especially CGHAZ, and it may affect the toughness;

- Low heat input $(0.4 \mathrm{~kJ} / \mathrm{mm})$ led to formation of high hardness microstructures, which can lead to toughness decrease. The carbon content was preponderant in brittle constituents' formation. Moreover, a combined effect between $\mathrm{Nb}$ addition and low heat input was noticed, an increase of hardenability was evident. Thus, a low heat input can negatively influence mechanical properties of the studied materials;

- $\quad \mathrm{Nb}$ addition led to smaller average grain size in CGHAZ, regardless heat input, when compared to $\mathrm{Nb}$ free steel. This was explained by the solubilization temperature of $\mathrm{Nb}$ which is higher compared to $\mathrm{V}$ as described by some authors [18]. Therefore, it indicates that the addition of niobium had a beneficial effect favoring the maintenance of the steel characteristics in terms of mechanical strength and, probably, toughness;

- Heat input and chemical composition caused deleterious effects on the HAZ regions, that is, dimensional and microstructural changes. However, non-observance of softness in any analyzed region was a highlight. Therefore, this indicates that, in terms of mechanical strength, no issues should occur after arc welding processes for the applied heat inputs.

\section{Acknowledgements}

The authors would like to acknowledge Federal Center for Technological Education of Minas Gerais (CEFET- MG) where trials were carried out. This work was supported by Coordenação de Aperfeiçoamento de Pessoal de Nível Superior Brazil (CAPES) - Financing Code 001. 


\section{References}

[1] Yang C, Wang Q. Research development and production of V-N microalloyed high strength rebars for building in China. Journal of Iron and Steel Research. 2008;15(2):81-86. http://dx.doi.org/10.1016/S1006-706X(08)60037-0.

[2] Panigrahi BK. Microstructure-related properties of some novel reinforcement bar steel. USA: ASM International; 2010. p. 287-293

[3] Lino RE, Prado J, Barbosa L, Oliveira FG, Reis L, Barbosa RANM. Development of high strength microalloyed coiled rebar. In: AISTech Conference Proceedings; 2017; Warrendale, Pennsylvania. Warrendale: Association for Iron \& Steel Technology; 2017.

[4] Santos J, Henriques AA. Strength and ductility of damaged tempcore rebars. Procedia Engineering. 2015;114:800-807. http://dx.doi.org/10.1016/j.proeng.2015.08.029.

[5] Lino RE. Laminação a quente de produtos longos microligados [thesis]. Belo Horizonte: Universidade Federal de Minas Gerais; 2018.

[6] Lino R, Guadanini LGL, Silva LB, Neto, JGC, Barbosa R. Effect of Nb and Ti addition on activation energy for austenite hot deformation. Journal of Materials Research and Technology-JMR\&T. 2018;8:1.

[7] Milbourn D, Yu L. Metallurgical benefits of vanadium microalloying in producing high strength seismic grade rebar. In: Proceedings of the International Seminar on Production and Application of HIgh Strength Seismic Grade Rebar Containing Vanadium; 2010; Beijing, China. Canadá: VANITEC; 2010. p. 32-43.

[8] Satyendra. Heat affected zone and weld metal properties in welding of steels. Greater Noida: IspatGuru; 2016 [access 5 sept. 2018 ]. Available from: http://ispatguru.com/heat-affected-zone-and-weld-metal-properties-in-welding-of-steels/

[9] Lancaster JF. Metalurgy of welding. England: Woodhead Publishing; 2007.

[10] Dong H, Xiaohu H, Deng D. Effect of welding heat input on microstructure and mechanical properties of HSLA steel joint. USA: ASM International; 2014. p. 138-146.

[11] Easterling K. Introduction of physical metallurgy of welding. UK: Butterworth-Heinemann; 1992. https://doi.org/10.1016/C2013-004524-0.

[12] Pavlina EJ, Van Tyne CJ. Correlation of yield strength and tensile strength with hardness for steels. USA: ASM International; 2008. p. 888893.

[13] Kou S. Welding metallurgy. USA: John Wiley \& Sons, Inc.; 2002. http://dx.doi.org/10.1002/0471434027.

[14]American Society for Testing and Materials. ASTM E92-17: standard test methods for vickers hardness and knoop hardness of metallic materials. West Conshohocken: ASTM International; 2017.

[15] American Society for Testing and Materials. ASTM E 112-96: standard test methods for determining average grain size. West Conshohocken: ASTM International; 2006.

[16] Montgomery DC, Runger GC. Applied statistics and probability for engineers. 3rd ed. Arizona State University, 2003.

[17] Zhang YQ, Zhang HQ, Li JF, Liu WN. Effect of heat input on microstructure and toughness of coarse grain heat affected zone in Nb microalloyed HSLA steels. Journal of Iron and Steel Research. 2009;16(5):73-80. http://dx.doi.org/10.1016/S1006-706X(10)60014-3.

[18]Gorni AA, Silveira JHD. Modelo matemático para o cálculo da solubilização em aços microligados ao nióbio, titânio e/ou vanádio. In: Anais do XXXI Seminário de Laminação da Associação Brasileira de Metalurgia e Materiais; 1994; Juiz de Fora. Juiz de Fora: ABM; 1994. p. 81-97.

[19] Losz JMB, Challenger KD. HAZ microestructures in HSLA steel weldments. Armco research and Technology. Ohio: University of Cincinnati; 1990.

[20] Thewlis G. Classification and quantification of microstructures in steels. Journal of Materials Science and Technology. 2004;20(2):143160. http://dx.doi.org/10.1179/026708304225010325.

[21] Oliveira F, Lino R, Barbosa R. Mathematical model of microstructural evolution of hot rolled wire rods for Nb microalloyed steels. Materials Science Forum. 2016;879:181-186. http://dx.doi.org/10.4028/www.scientific.net/MSF.879.181. 